\title{
Interaction of New Zealand Ironsand and Flux Materials
}

\author{
Zhe WANG ${ }^{1)}$ David PINSON, ${ }^{2)}$ Sheng CHEW, ${ }^{2)}$ Harold ROGERS, ${ }^{2)}$ Brian Joseph MONAGHAN ${ }^{1)}$ and \\ Guangqing $\mathrm{ZHANG}^{1 \text { )* }}$
}

1) School of Mechanical, Materials and Mechatronic Engineering, University of Wollongong, Wollongong, NSW 2522 Australia.

2) BlueScope, Steelmaking Technology and Planning, P.O. Box 202, Port Kembla, NSW 2505 Australia.

(Received on December 15, 2015; accepted on May 9, 2016; J-STAGE Advance published date: June 7, 2016)

\begin{abstract}
New Zealand ironsand is mined for steel production. Its composition approximates that of titanomagnetite $\left(\mathrm{Fe}_{3-x} \mathrm{Ti}_{x} \mathrm{O}_{4}\right)$ containing about $60 \mathrm{wt} \%$ iron and $8 \mathrm{wt} \%$ titania. The ironsand provides an alternative source of iron to conventional iron ores. Its addition into a sinter blend is an established method of utilisation in ironmaking. Knowledge of the interaction between ironsand and flux materials during sintering is helpful to understand the sintering mechanism of titanomagnetite. In this study, two-layer interaction couples between ironsand and flux materials ( $\mathrm{CaO}, \mathrm{MgO}$ and dolomite) were prepared and sintered in an atmosphere of $\mathrm{pO}_{2}=0.5 \mathrm{kPa}$ in the temperature range of $1200-1300^{\circ} \mathrm{C}$ for different times. When the ironsand was sintered with $\mathrm{MgO}, \mathrm{Mg}^{2+}$ ions significantly diffused into the lattice of ironsand, which stabilised the system of $\mathrm{FeO}_{x}-\mathrm{MgO}$ and hindered the assimilation of ironsand particles. During the sintering of ironsand with $\mathrm{CaO}$, a reaction zone consisting of perovskite and calcium ferrite formed between the two layers. In comparison, a reaction zone consisting of perovskite, $\mathrm{MgO}-\mathrm{FeO}$ solid solution and calcium ferrite occurred during the sintering of ironsand with dolomite. Increasing sintering temperature significantly enhanced the penetration of calcium ferrite into the dolomite layer; whereas the perovskite phase and $\mathrm{MgO}-\mathrm{FeO}$ solid solution remained at higher sintering temperatures due to their relatively high melting points.
\end{abstract}

KEY WORDS: sintering; ironsand; titanomagnetite; dolomite; calcia; magnesia.

\section{Introduction}

Ironsand deposits along the west coast of New Zealand's North Island, including those at Waikato North Head and Taharoa, are mined for iron and steel production. ${ }^{1)}$ The composition and microstructure of New Zealand ironsand have been intensively examined. ${ }^{1-4)}$ Although the composition of ironsand is partially dependant on origin/location, it approximates that of titanomagnetite $\left(\mathrm{Fe}_{3-\mathrm{x}} \mathrm{Ti}_{\mathrm{x}} \mathrm{O}_{4}\right)$ containing about $60 \mathrm{wt} \%$ iron and $8 \mathrm{wt} \%$ titania $\left(\mathrm{TiO}_{2}\right) .{ }^{1-3)}$ The major impurities in the ironsand include $\mathrm{Al}_{2} \mathrm{O}_{3}, \mathrm{MgO}$, $\mathrm{SiO}_{2}, \mathrm{~V}_{2} \mathrm{O}_{5}$, and $\mathrm{MnO}$ - all but $\mathrm{SiO}_{2}$ are typically associated with the titanomagnetite grains, occurring as solid solution components within the lattice. The other impurity elements, including part of the aluminium, are more typically associated with gangue mineral grains such as aluminosilicates (e.g. feldspars and clays), quartz and apatite. ${ }^{4)}$

New Zealand ironsand grains can be divided into two types: homogeneous grains and grains that contain exsolution lamellae. Cocker et al. ${ }^{1)}$ examined New Zealand ironsand using electron microprobe analyses and found that homogeneous titanomagnetite particles accounted for 90 to $95 \mathrm{vol} \%$ and were relatively rich in $\mathrm{Ti}$, containing up to 8.2 $\mathrm{wt} \% \mathrm{TiO}_{2}$. The exsolution lamellae appearing as bands of

\footnotetext{
* Corresponding author: E-mail: gzhang@uow.edu.au DOI: http://dx.doi.org/10.2355/isijinternational.ISIJINT-2015-728
}

variable thickness in a trellis-like pattern were of hematiteilmenite composition with an overall high $\mathrm{TiO}_{2}$ content of $13.1 \mathrm{wt} \%$, while the titanomagnetite host was relatively low in $\mathrm{Ti}$ (about $1.5 \mathrm{wt} \% \mathrm{TiO}_{2}$ ). High-temperature oxidation of $\mathrm{Fe}^{2+}$ to $\mathrm{Fe}^{3+}$ in titanomagnetite can produce vacancies in octahedral sites of the $\{111\}$ crystal planes, which allows increased diffusion of $\mathrm{Ti}$ into these regions and leads to the formation of hematite-ilmenite lamellae $(1-10 \mu \mathrm{m})$ along the original $\{111\}$ planes of the titanomagnetite host. ${ }^{5}$ )

The ironsand provides an alternative source of iron to conventional iron ores. Its small particle size precludes direct charging into a blast furnace but its incorporation into sinter provides an appropriate method for its utilisation in ironmaking. ${ }^{6)}$ The behaviour of ironsand during iron ore sintering has been examined previously. ${ }^{4)}$ It was reported that the assimilation of ironsand during sintering in a reducing atmosphere started from the diffusion of calcium into the lattice of the ironsand matrix, which further decreased the melting point of titanomagnetite and accelerated the melting rate of ironsand particles. A reaction zone was formed within the ironsand particle where a perovskite $\left(\mathrm{CaO} \cdot \mathrm{TiO}_{2}\right)$ phase was generated as the result of the reaction between $\mathrm{TiO}_{2}$ and $\mathrm{CaO}$.

This paper is focused on characterising the interaction between ironsand and flux materials $(\mathrm{CaO}, \mathrm{MgO}$ and dolomite) in the context of iron ore sinter blends containing titanomagnetite to gain a better understanding of the sintering 
mechanism of titanomagnetite.

\section{Experimental Procedure}

\subsection{Sample Preparation}

The starting materials used in the interaction experiments were: New Zealand ironsand and three fluxes including synthetic calcia, $\mathrm{CaO}$ (Sigma Aldrich, reagent grade); synthetic magnesia, $\mathrm{MgO}$ (Sigma Aldrich, 99\%, <325 mesh) and dolomite. The synthetic $\mathrm{CaO}$ powder was calcined at $1000^{\circ} \mathrm{C}$ for $2 \mathrm{~h}$. Ironsand and dolomite were supplied by BlueScope Ltd. and the chemical compositions examined by X-ray fluorescence (XRF) were reported previously. Detailed characterisation of the ironsand has also been presented in the Ref. 4). Before use, dolomite was crushed and screened to a particle size less than $38 \mu \mathrm{m}$. The decomposition of dolomite particles during sintering with release of $\mathrm{CO}_{2}$ increases the porosity of the formed $\mathrm{MgO}-\mathrm{CaO}$ layer, and so may affect the contact area between ironsand and the $\mathrm{MgO}-\mathrm{CaO}$ mixture. However, this affects the diffusion rates of all related elements between an interaction couple proportionally. It makes no difference to using a pure $\mathrm{MgO}-\mathrm{CaO}$ mixture except for the overall diffusion extent achieved.

The interaction couple between ironsand and each flux material used in this work was prepared as follows. Ironsand particles $(0.5 \mathrm{~g})$ were first placed in a die with a diameter of $8 \mathrm{~mm}$ and pressed into a substrate in a uniaxial hydraulic press by applying $20 \mathrm{kN}$ of pressure for $2 \mathrm{~min}$. Then, $0.3 \mathrm{~g}$ of each flux material powder was placed into the same die and pressed with the ironsand substrate into an interaction couple by applying $20 \mathrm{kN}$ of pressure for $2 \mathrm{~min}$.

\subsection{Sintering}

The sintering apparatus has been described previously. $\left.{ }^{4}\right)$ The setup is based on a vertical tube furnace with a working diameter of $55 \mathrm{~mm}$ through which a gas mixture of controlled composition can be continuously passed. Experiments were conducted at different temperatures (1 200, 1250,1300 and $1325^{\circ} \mathrm{C}$ ) for three different times (4, 8 and $20 \mathrm{~min}$ ) in an atmosphere of $\mathrm{pO}_{2}=0.5 \mathrm{kPa}$ (representative of industrial iron ore sintering ${ }^{7)}$ ) maintained by an air-argon mixture. The furnace was preheated to a designated temperature, and then purged with the gas mixture for at least $20 \mathrm{~min}$ before a crucible with the interaction couples was suspended in the hot zone of the furnace. After sintering for a desired time, the samples were cooled rapidly by lifting the crucible to the cold top end of the tube furnace in order to avoid any possible transformation due to slow cooling.

\subsection{Microstructure Analysis}

After cooling to room temperature, the specimens were vacuum infiltrated by epoxy resin, and after hardening, sectioned perpendicular to the ironsand-flux interface. The section was ground and polished to a $1 \mu \mathrm{m}$ finish for optical microscopic observation (Leica DM6000 Optical Microscope). The polished samples were then coated with carbon prior to analysis by scanning electron microscopy (SEM, JEOL JCM-6000) operated at $15 \mathrm{kV}$. The thickness of the reaction layers reported represents an average of 12 measurements of the layers.

\section{Results and Discussion}

\subsection{Interaction between Ironsand and $\mathrm{MgO}$}

The interaction couples between ironsand and $\mathrm{MgO}$ were sintered in an atmosphere of $\mathrm{pO}_{2}=0.5 \mathrm{kPa}$ in the temperature range of $1200-1300^{\circ} \mathrm{C}$ for different times. Figure 1 presents the back-scattered electron (BSE) images of typical ironsand particles in direct contact with the $\mathrm{MgO}$ layer in the interaction couples sintered under different conditions. The BSE image of the interface marked in Fig. 1(b) is shown in Fig. 1(c) at a higher magnification. These sintered ironsand particles remained intact and there was no obvious morphology change due to the reaction between ironsand and $\mathrm{MgO}$. There was some evidence of bonding (see the area inside the circle in Fig. $1(\mathrm{~b})$ ) at $1300^{\circ} \mathrm{C}$, likely due to a reaction with a silicate phase. This was not observed in
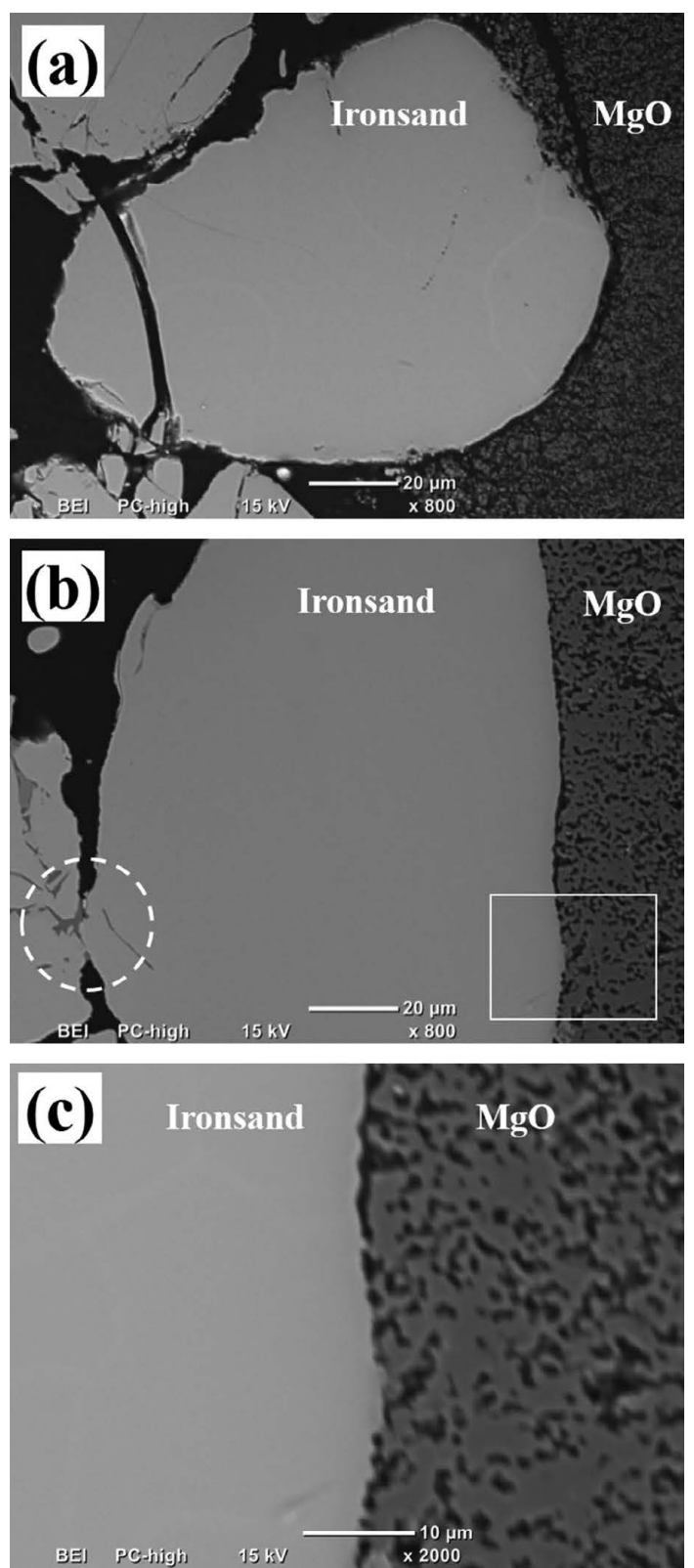

Fig. 1. Back-scattered electron (BSE) images of typical ironsand particles close to the $\mathrm{MgO}$ layer in the interaction couples between ironsand and $\mathrm{MgO}$ sintered under different conditions. (a) $1250^{\circ} \mathrm{C}, 4 \mathrm{~min}$; (b) $1300^{\circ} \mathrm{C}, 8 \mathrm{~min}$; (c) $1300^{\circ} \mathrm{C}$, $8 \mathrm{~min}$, high magnification. 
the sample sintered at $1250^{\circ} \mathrm{C}$ (Fig. 1(a)).

Figure 2 shows the chemical composition across the interface between ironsand and $\mathrm{MgO}$ in a sample sintered at $1200^{\circ} \mathrm{C}$ for $4 \mathrm{~min}$. The velocity of diffusion of an element in a solid phase can be described by the distance it diffuses in a certain time. The original ironsand particles contained about $3 \mathrm{wt} \% \mathrm{Mg}$ in the titanomagnetite phase according to SEM/EDS analysis. After 4 min sintering, the Mg content was increased to about $9 \mathrm{wt} \%$ throughout the particle. Similarly, the Fe content in the $\mathrm{MgO}$ layer increased from nil to $5 \mathrm{wt} \%$. In comparison, the spot analysis showed that the magnesia layer near the interface practically contained no $\mathrm{Ti}$. The result shows that the diffusion of $\mathrm{Mg}$ within the titanomagnetite particle and iron in $\mathrm{MgO}$ was fast, however, $\mathrm{Ti}$ is hard to diffuse into the $\mathrm{MgO}$ phase.

Generally, one ion may take the place of another to form a solid-solution series if the difference between their ionic radii does not exceed $15 \%$ of the radius of the smaller ion. ${ }^{8)}$ Magnetite has an inverse spinel structure in which 50\% of $\mathrm{Fe}^{3+}$ (4 coordinates, ionic radius $63 \mathrm{pm}$ ) occupies the trtradedral sites, while the other $50 \%$ of $\mathrm{Fe}^{3+}$ (6 coordinates high spin, ionic radius $78.5 \mathrm{pm})$ and all $\mathrm{Fe}^{2+}(6$ coordinates high spin, ionic radius $92 \mathrm{pm}$ ) occupy the octohedral sites. $\mathrm{Mg}^{2+}$ ion (86 pm) and $\mathrm{Fe}^{2+}$ can substitute each other without distorting the overall structures of minerals due to their similar atomic size and identical electric charge. ${ }^{9)}$ In this study, during sintering at a high temperature, $\mathrm{Mg}^{2+}$ ions from $\mathrm{MgO}$ diffused into the lattice of titanomagnetite to form $\mathrm{MgFe}_{2} \mathrm{O}_{4}-\mathrm{Fe}_{3} \mathrm{O}_{4}$ solid solution, and simultaniously $\mathrm{Fe}^{2+}$ ions diffused in the opposite direction into $\mathrm{MgO}$. $\mathrm{Ti}^{4+}$ $(74.5 \mathrm{pm})$ or $\mathrm{Ti}^{3+}(81 \mathrm{pm})$ ions are likely present as substituents of the $\mathrm{Fe}^{3+}$ ions at the octohedral sites considering their valency and radii. In comparison to $\mathrm{Fe}$ ions, Ti ions are more difficult to diffuse due to its higher electronic affinity
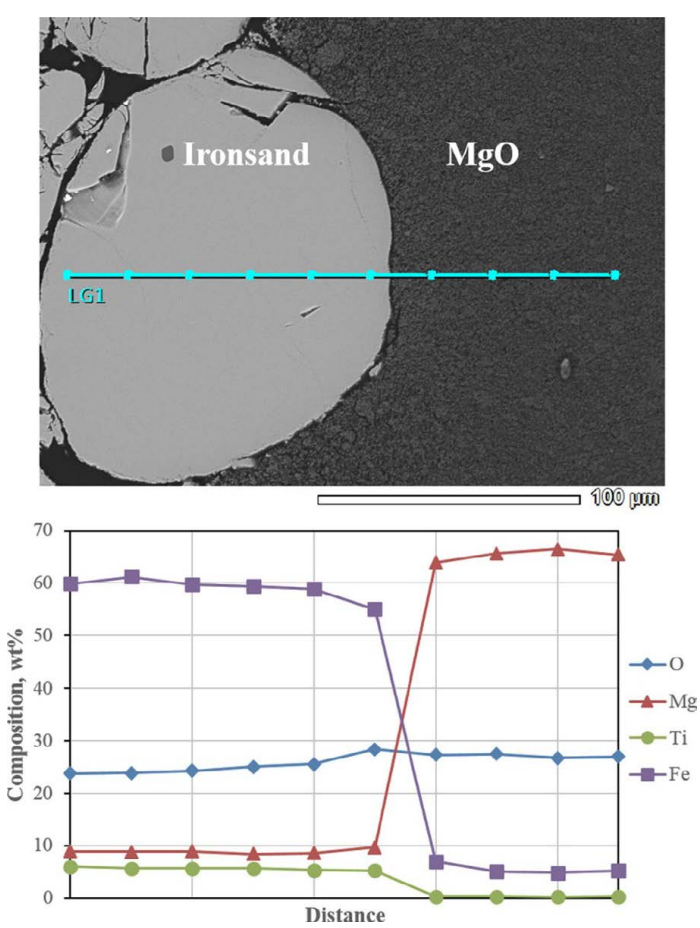

Fig. 2. BSE image and the chemical composition near the interface between ironsand and $\mathrm{MgO}$ layers in a sample sintered at $1200^{\circ} \mathrm{C}$ for $4 \mathrm{~min}$. (Online version in color.) and stronger binding with surrounding oxygen ions. They are also hard to diffuse into $\mathrm{MgO}$ due to the difference in their valency; a $\mathrm{Ti}^{4+}$ ion needs to replace two $\mathrm{Mg}^{2+}$ ions to keep local electrical neutrality which has high spacial and chemical resistivities.

Figure 3 presents a BSE image of typical ironsand particles in a sample sintered at $1300^{\circ} \mathrm{C}$ for $8 \mathrm{~min}$, and the chemical compositions at different points marked in Fig. 3 are listed in Table 1. It should be noted that when an elemental content is less than $1 \mathrm{wt} \%$, the number is only indicative due to the accuracy limits of EDS analysis. Points 1 and 2 represent the relict titanomagnetite particles in which the $\mathrm{Mg}$ content increased to over $8 \mathrm{wt} \%$. Besides enhanced diffusion of ions, the higher sintering temperature also improved the sintering of ironsand particles. As shown in Fig. 3, although the contour of each ironsand particle remained intact, they were bonded together by a silicate phase (Points 3 and 4). During sintering at the high temperature, a small amount of silicate phase with low melting point was generated and melted due to the presence of impurities in the original ironsand, which was beneficial to the aggregation of ironsand particles. It is noted that the silicate phase contained approximately $7 \mathrm{wt} \%$ of $\mathrm{Mg}$ and $\mathrm{Ca}$. The diffusion of $\mathrm{Mg}$ to the contacts between ironsand particles is likely to assist the formation of a liquid silicate phase.

However, significant diffusion of $\mathrm{Mg}^{2+}$ ions into the $\mathrm{Fe}_{3} \mathrm{O}_{4}$ lattice of ironsand can stabilise the system of $\mathrm{FeO}_{\mathrm{x}}-$ $\mathrm{MgO}$ and hinder the dissolution of ironsand particles. As shown in Fig. 4, the liquidus temperature of the $\mathrm{FeO}_{\mathrm{x}}-\mathrm{MgO}$ system $^{10)}$ increases gradually with increasing $\mathrm{MgO}$ content.

\subsection{Interaction between Ironsand and $\mathbf{C a O}$}

The interaction couples between ironsand and $\mathrm{CaO}$ were

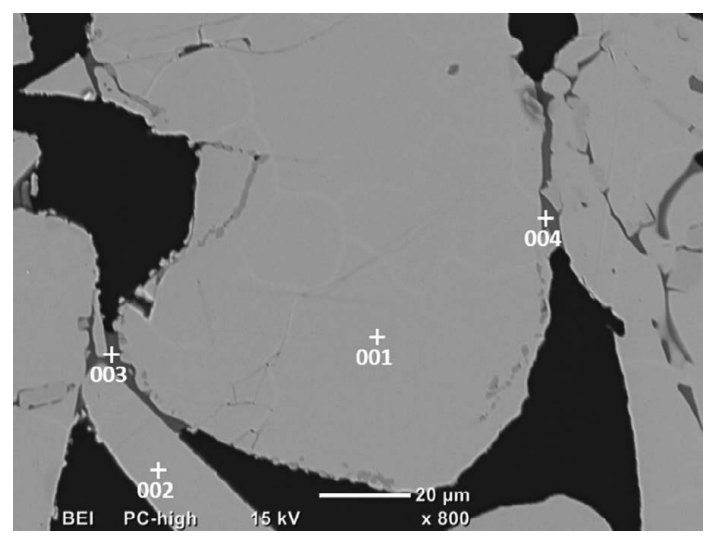

Fig. 3. BSE images of typical ironsand particles in the interaction couples between ironsand and $\mathrm{MgO}$ sintered at $1300^{\circ} \mathrm{C}$ for $8 \mathrm{~min}$.

Table 1. Elemental compositions (wt\%) at the points marked in Fig. 3 and corresponding phases.

\begin{tabular}{cccccccc}
\hline Point no. & $\mathrm{Fe}$ & $\mathrm{Ca}$ & $\mathrm{Ti}$ & $\mathrm{Mg}$ & $\mathrm{Si}$ & $\mathrm{Al}$ & Phase identified \\
\hline 1 & 62.0 & 0.1 & 5.2 & 8.1 & 0.1 & 1.9 & Titanomagnetite \\
2 & 61.5 & 0.1 & 5.5 & 8.7 & 0.2 & 2.1 & Titanomagnetite \\
3 & 12.3 & 7.6 & 3.2 & 7.6 & 22.5 & 6.9 & Silicate \\
4 & 12.2 & 7.8 & 3.8 & 7.3 & 23.6 & 6.6 & Silicate \\
\hline
\end{tabular}


sintered in an atmosphere of $\mathrm{pO}_{2}=0.5 \mathrm{kPa}$ in the temperature range of $1200-1325^{\circ} \mathrm{C}$ for different times. The microstructure of formed mineral phases was examined by optical microscope and SEM/EDS.

A reaction zone between the ironsand and $\mathrm{CaO}$ layers was generated in the specimens during sintering in this study. Figure 5 presents the BSE images of the interface between the ironsand and $\mathrm{CaO}$ layer sintered under different conditions. As shown in Fig. 5(a), a reaction zone with a width of approximately $3 \mu \mathrm{m}$ was formed at the boundary of ironsand particles and $\mathrm{CaO}$ sintered at $1200^{\circ} \mathrm{C}$ for $4 \mathrm{~min}$. The reaction zone thickness increased with increasing sintering time (see Fig. 5(b)), showing a reaction zone of thickness of $\sim 12 \mu \mathrm{m}$ after $20 \mathrm{~min}$. A morphological change of the

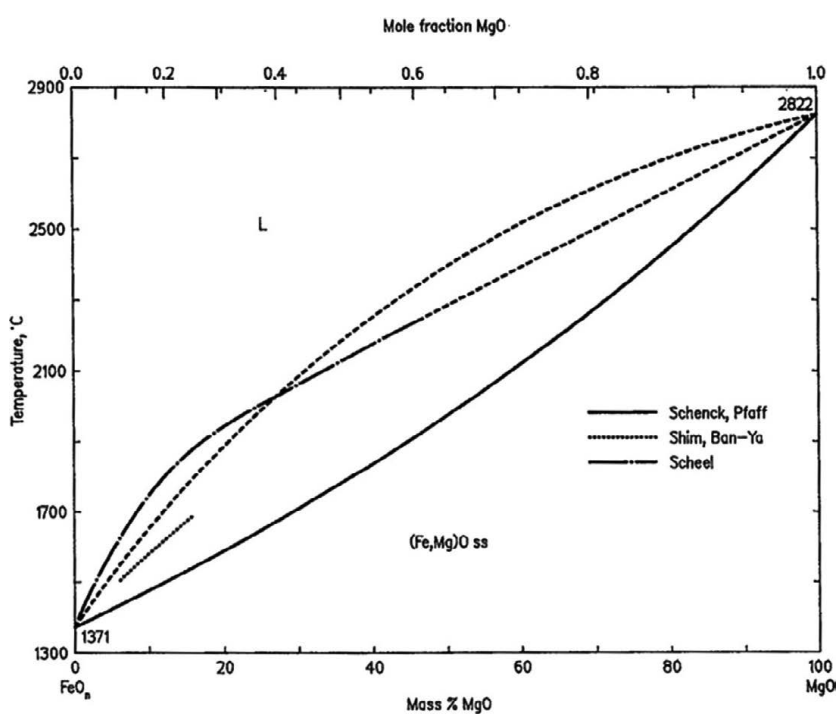

Fig. 4. Liquidus temperature of $\mathrm{FeOx}-\mathrm{MgO}$ system. ${ }^{10)}$ reaction zone with sintering temperature was also observed. Figure 5(c) shows the interface between the ironsand and $\mathrm{CaO}$ layers in samples sintered at $1250^{\circ} \mathrm{C}$ for $4 \mathrm{~min}$ and the thickness of the reaction zone increased to approximately $8 \mu \mathrm{m}$. When sintered at $1300^{\circ} \mathrm{C}$ for $4 \mathrm{~min}$, the average thickness of the reaction zone increased significantly to about $30 \mu \mathrm{m}$, as shown in Fig. 5(d).

Figure 6 shows the BSE image and elemental distribution of a reaction zone between ironsand and $\mathrm{CaO}$ in a specimen heated at $1200^{\circ} \mathrm{C}$ for $20 \mathrm{~min}$. The chemical compositions at different points presented in Fig. 6 were examined by EDS analysis and are listed in Table 2 . The reaction zone contained a high concentration of $\mathrm{Ca}$ which was relatively uniformly distributed. However it can be noted from the distributions of $\mathrm{Fe}$ and $\mathrm{Ti}$ that there was a narrow band within the reaction zone next to the titanomagnetite matrix, corresponding to a band in the BSE image with a slightly darker colour. EDS analysis shows that the band (point 3) had a distinct composition from the major part of the reaction zone (points 4 and 5), but was the same as those distributed dark areas (point 2) within the titanomagnetite matrix. As shown in Table 2, the major part of the reaction zone was dominated by a calcium ferrite phase containing about $27 \mathrm{wt} \% \mathrm{Ca}$ and $36 \mathrm{wt} \%$ iron, while the Ti-rich subzone and the distributed dark areas in the titanomagnetite matrix was a perovskite phase of $\mathrm{Fe}$ and $\mathrm{Ca}$, containing 16-24 wt $\%$ of Ti. Similar perovskite phase was also found around the peripheries of some relict ironsand particles in an industrial sinter with addition of $3 \mathrm{wt} \%$ of ironsand. ${ }^{4}$

Point 6 in Fig. 6 proved to be in the lime layer, which also contained low levels of iron (3.71 wt\%). Problems in sample preparation resulted in some loss of $\mathrm{CaO}$. As a result the $\mathrm{CaO}$ side of the ironsand- $\mathrm{CaO}$ couple shown in Fig. 6 was not in the same plane as the other part of the sample, mak-
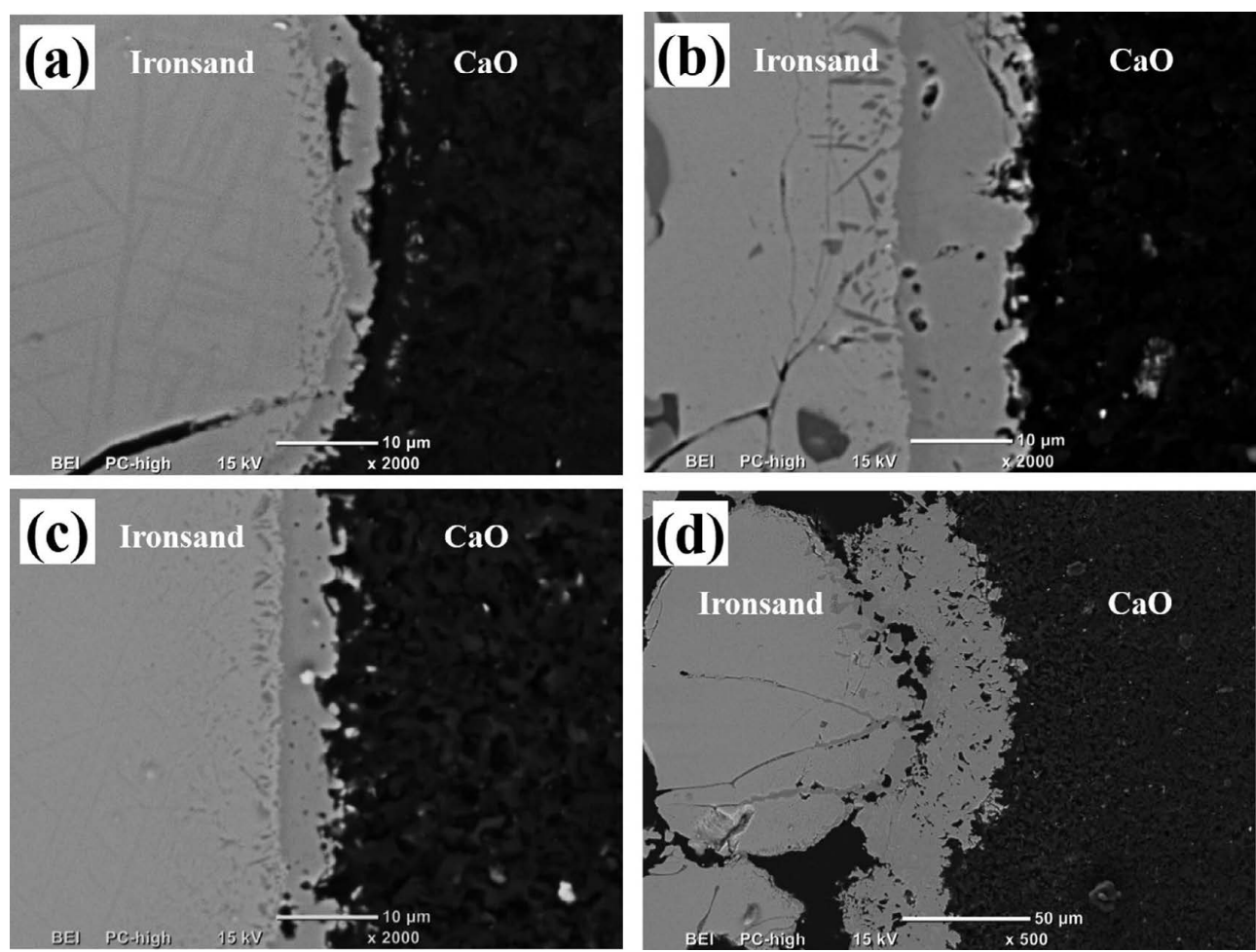

Fig. 5. BSE images of the interaction couples of ironsand and $\mathrm{CaO}$ sintered under different conditions. (a) $1200^{\circ} \mathrm{C}$, $4 \mathrm{~min}$; (b) $1200^{\circ} \mathrm{C}, 20 \mathrm{~min}$; (c) $1250^{\circ} \mathrm{C}, 4 \mathrm{~min}$; (d) $1300^{\circ} \mathrm{C}, 4 \mathrm{~min}$. 

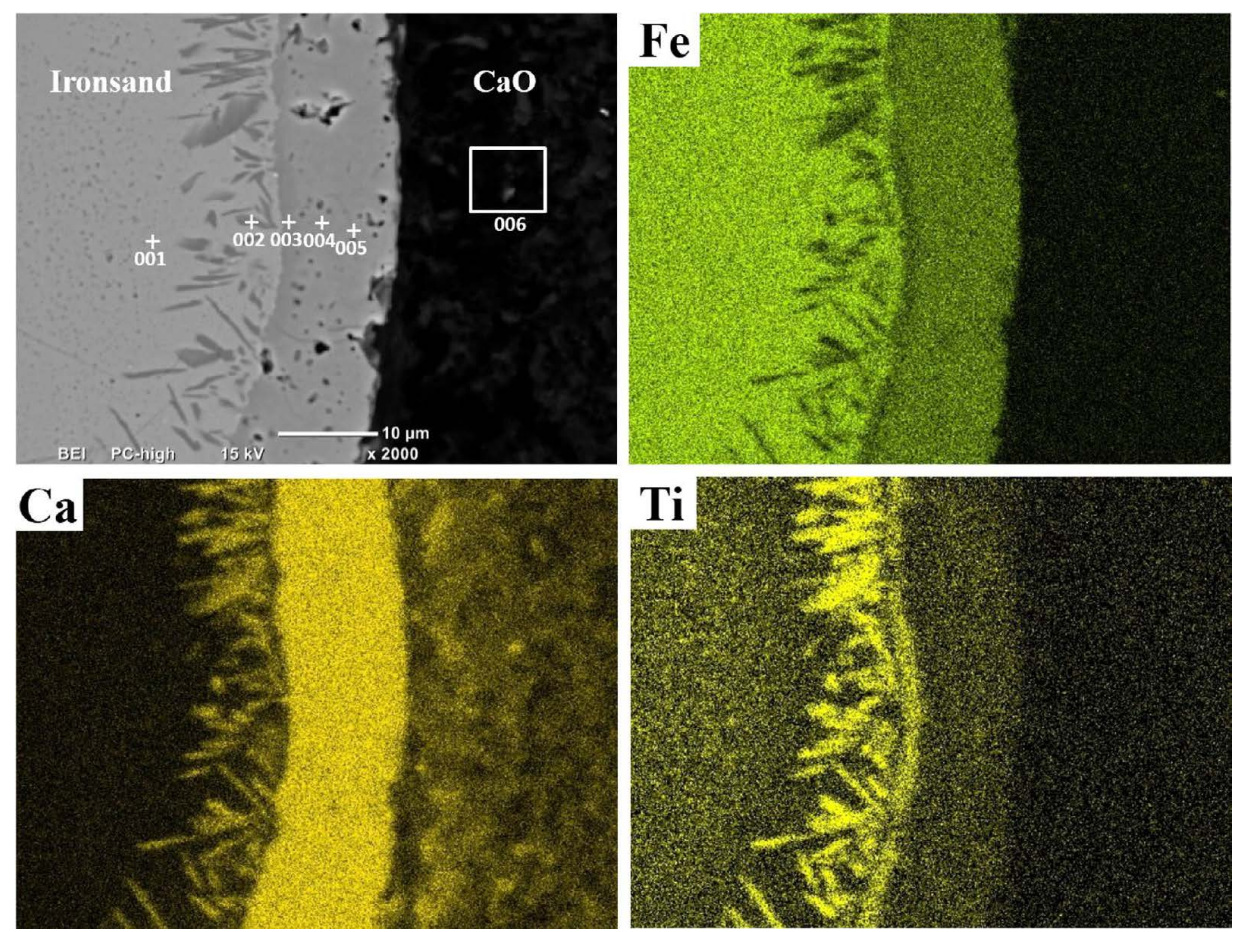

Fig. 6. BSE image and EDS mapping of a reacted zone between ironsand and $\mathrm{CaO}$ in a specimen sintered at $1200^{\circ} \mathrm{C}$ for $20 \mathrm{~min}$. (Online version in color.)
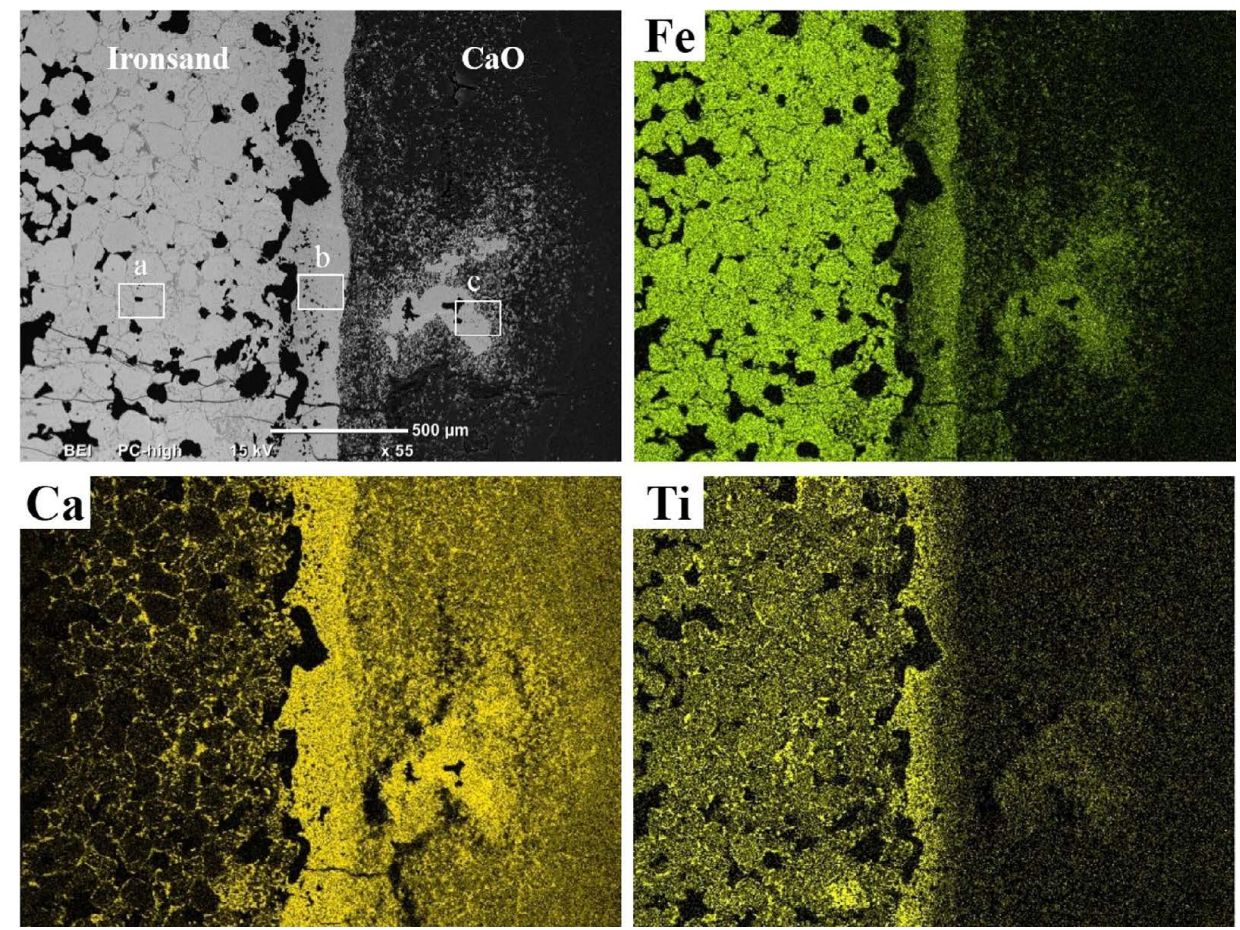

Fig. 7. BSE image and EDS mapping of an interaction couple between ironsand and $\mathrm{CaO}$ sintered at $1300^{\circ} \mathrm{C}$ for 20 min. The details of the small areas marked as a, b and c are presented in Fig. 8. (Online version in color.)

Table 2. Elemental composition (wt $\%$ ) of grains marked in Fig. 6 and corresponding phases.

\begin{tabular}{cccccccc}
\hline Point no. & $\mathrm{Fe}$ & $\mathrm{Ca}$ & $\mathrm{Ti}$ & $\mathrm{Mg}$ & $\mathrm{Si}$ & $\mathrm{Al}$ & Phase identified \\
\hline 1 & 63.8 & 1.0 & 2.48 & 3.5 & 0.3 & 2.7 & Titanomagnetite \\
2 & 14.5 & 24.0 & 23.6 & 0.3 & 0.4 & 0.6 & Perovskite \\
3 & 22.3 & 27.7 & 16.0 & 0.2 & 2.8 & 1.4 & Perovskite \\
4 & 35.7 & 27.4 & 1.3 & 0.2 & 0.8 & 2.0 & Calcium ferrite \\
5 & 36.2 & 27.0 & 1.2 & 0.4 & 0.3 & 1.4 & Calcium ferrite \\
6 & 3.7 & 57.9 & 0.1 & 2.0 & 0.6 & 0.1 & $\mathrm{CaO}$
\end{tabular}

ing the absolute signal strength of $\mathrm{Ca}$ in this area weaker.

It is known that the reactions between $\mathrm{CaO}$ and $\mathrm{Fe}_{2} \mathrm{O}_{3}$ or $\mathrm{TiO}_{2}$ are favoured thermodynamically which can be presented as follows:

$$
\begin{aligned}
& \mathrm{CaO}(\mathrm{s})+\mathrm{Fe}_{2} \mathrm{O}_{3}(\mathrm{~s})=\mathrm{CaFe}_{2} \mathrm{O}_{4}(\mathrm{~s}) \\
& \Delta \mathrm{G}^{\circ}=-29519-9.93 \mathrm{~T}(\mathrm{~J}) \\
& \mathrm{CaO}(\mathrm{s})+\mathrm{TiO}_{2}(\mathrm{~s})=\mathrm{CaTiO}_{3}(\mathrm{~s}) \\
& \Delta \mathrm{G}^{\circ}=-80150-6.47 \mathrm{~T}(\mathrm{~J})
\end{aligned}
$$


The standard Gibbs free energy changes of the reactions were calculated using data from Binnewies and Milke ${ }^{11)}$ in the range of 1200 to $1325^{\circ} \mathrm{C}$. Thermodynamically, the reaction between $\mathrm{TiO}_{2}$ and $\mathrm{CaO}$ is favoured over that between $\mathrm{Fe}_{2} \mathrm{O}_{3}$ and $\mathrm{CaO}$.

When the interaction couples of ironsand and $\mathrm{CaO}$ were sintered, $\mathrm{Ca}^{2+}$ ions (with radius $114 \mathrm{pm}$ ) from $\mathrm{CaO}$ diffused into the lattice of $\mathrm{Fe}_{3} \mathrm{O}_{4}$, while $\mathrm{Fe}^{2+}, \mathrm{Fe}^{3+}$ and $\mathrm{Ti}^{4+}$ ions from ironsand diffused in the opposite direction into $\mathrm{CaO}$. As a result, a reaction zone which was rich in $\mathrm{Ca}, \mathrm{Fe}$ and Ti was generated between the two layers. Due to the low diffusivity of $\mathrm{Ti}^{4+}$, it was accumulated near the titanomagnetite matrix boundary and combined with relatively mobile $\mathrm{Ca}^{2+}$ and formed the perovskite phase. $\mathrm{Ca}^{2+}$ also diffused inside the titanomagnetite matrix and formed distributed perovskite phase where the Ti content was much higher than the average after Fe diffused away. Meanwhile, a calcium ferrite phase was formed close to the $\mathrm{CaO}$ layer due to the reaction between $\mathrm{CaO}$ and iron oxides and the relatively higher diffusion rates of $\mathrm{Fe}^{2+}$ and $\mathrm{Fe}^{3+}$. It is interesting that the difference between the radii of $\mathrm{Ca}^{2+}$ and the octahedral $\mathrm{Fe}^{2+}$ ions is up to $24 \%$, yet $\mathrm{Ca}^{2+}$ can quickly diffuse in the titanomagnetite lattice. The reason behind may be that substitution of octahedral $\mathrm{Fe}^{3+}$ ions by smaller $\mathrm{Ti}^{4+}$ ions with higher electron affinity creates more space for $\mathrm{Ca}^{2+}$ next to the coordinating $\mathrm{O}^{2-}$ ions. On the other hand, iron diffused into the $\mathrm{CaO}$ layer perhaps via a surface diffusion mechanism. Fine $\mathrm{CaO}$ powder provided high surface area for the diffusion to take place.

Figure 7 shows the BSE image and EDS mapping of an interaction couple between ironsand and $\mathrm{CaO}$ heated at $1300^{\circ} \mathrm{C}$ for $20 \mathrm{~min}$. A coarsened reaction zone was observed around the interface of the two layers whose development may have been affected by separation from the ironsand layer. The Ti rich and Fe rich bands in the reaction zone can be clearly identified from the $\mathrm{Fe}$ and $\mathrm{Ti}$ distributions. A part of Fe-rich subzone penetrated into $\mathrm{CaO}$ layer (region ' $c$ '), which was repeated in specimens sintered at this severe sintering condition, but was never observed in other conditions. This excludes the possibility of mixing ironsand particles into the $\mathrm{CaO}$ layer, and penetration of $\mathrm{Fe}$ into $\mathrm{CaO}$ was through diffusion of $\mathrm{Fe}$. It can also been seen that $\mathrm{Ca}$ penetrated deeply into the ironsand layer and distributed between the titanomagnetite particles.

The BSE images of three different typical areas in Fig. 7 are shown in Fig. 8 with higher magnification. The chemical compositions at different points presented in Fig. 8 obtained by EDS analysis are summarised in Table 3. Figure 8(a) represents the microstructure of the ironsand layer after sintering. Although ironsand boundaries were still clearly seen, they were intimately bonded by a perovskite phase (Points 3 and 4) and a lesser amount of silicate phase (Point 5). The reaction zone presented in Fig. 8(b) consisted of perovskite (Points 6 and 7) and calcium ferrite (Points 8 and 9) phases. Small amounts of iron oxides were also finely distributed in the reaction zone (Points 10 and 11). Figure 8(c) shows the microstructure of calcium ferrite penetrated into the $\mathrm{CaO}$ layer. Many calcium ferrite particles were aggregated together (as represented by Point 12) as well as finely distributed in the $\mathrm{CaO}$ layer (Point 13).

Enhanced sintering conditions (higher temperature and
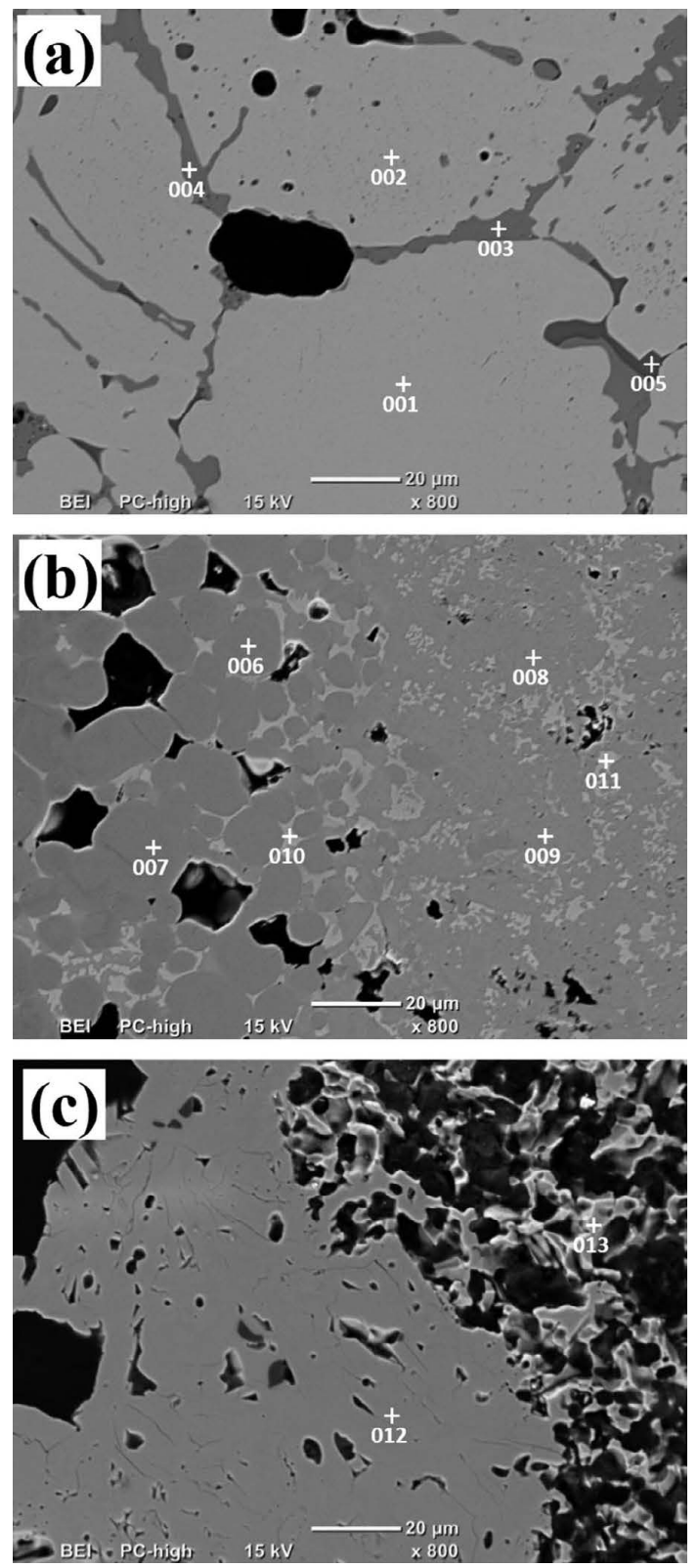

Fig. 8. Higher magnification BSE images of the areas marked in Fig. 7.

longer sintering time) significantly improved the assimilation between ironsand and $\mathrm{CaO}$ and correspondingly resulted in a coarsened reaction zone. The formation of low melting point calcium ferrite phase in the Fe-rich subzone greatly promoted mass transfer and further penetration of calcium ferrite into the $\mathrm{CaO}$ layer. In contrast, the $\mathrm{TiO}_{2}$ rich subzone became wider and did not melt since $\mathrm{TiO}_{2}$ stablised the system of $\mathrm{CaO}-\mathrm{TiO}_{2}-\mathrm{FeO}_{\mathrm{x}}{ }^{10)}$ and hindered its dissolution any further (Fig. 9). The liquidus temperature increases gradually with the introduction of $\mathrm{TiO}_{2}$ along the tie-line from $\mathrm{CaO} \cdot \mathrm{Fe}_{2} \mathrm{O}_{3}$ (mono calcium ferrite) to $\mathrm{CaO} \cdot \mathrm{TiO}_{2}$ (perovskite).

\subsection{Interaction between Ironsand and Dolomite}

Investigation of the decomposition of dolomite showed that under $\mathrm{CO}_{2}$ the reaction takes place in two distinct stages. Dolomite decomposes into calcite and magnesium oxide in the range of $550-800^{\circ} \mathrm{C}$ (Reaction 3), and then calcite dissociates (Reaction 4) in the range of $900-960^{\circ} \mathrm{C}$. 
Table 3. Elemental composition (wt $\%$ ) of grains marked in Fig. 8 and corresponding phases.

\begin{tabular}{cccccccc}
\hline Point no. & $\mathrm{Fe}$ & $\mathrm{Ca}$ & \multicolumn{1}{c}{$\mathrm{Ti}$} & $\mathrm{Mg}$ & $\mathrm{Si}$ & $\mathrm{Al}$ & Phase identified \\
\hline 1 & 71.4 & 0.7 & 3.5 & 1.6 & 0.3 & 1.5 & Titanomagnetite \\
2 & 69.4 & 1.1 & 4.4 & 1.4 & 0.5 & 1.6 & Titanomagnetite \\
3 & 12.0 & 27.8 & 23.7 & 0.3 & 1.0 & 0.7 & Perovskite \\
4 & 10.8 & 27.2 & 26.0 & 0.2 & 0.8 & 0.6 & Perovskite \\
5 & 11.8 & 30.1 & 3.8 & 0.5 & 13.2 & 3.6 & Silicate \\
6 & 29.0 & 29.4 & 9.4 & 0.4 & 1.6 & 1.1 & Perovskite \\
7 & 26.9 & 28.2 & 10.7 & 0.5 & 1.4 & 1.0 & Perovskite \\
8 & 36.6 & 28.6 & 2.4 & 0.4 & 0.8 & 1.4 & Calcium ferrite \\
9 & 37.6 & 28.9 & 2.3 & 0.3 & 0.9 & 1.6 & Calcium ferrite \\
10 & 65.5 & 3.6 & 0.5 & 4.4 & 0.2 & 1.7 & Iron oxides \\
11 & 66.1 & 3.7 & 0.7 & 4.3 & 0.3 & 1.6 & Iron oxides \\
12 & 37.3 & 28.6 & 1.8 & 0.7 & 0.6 & 1.4 & Calcium ferrite \\
13 & 31.4 & 24.9 & 1.6 & 1.1 & 0.5 & 1.4 & Calcium ferrite \\
\hline
\end{tabular}
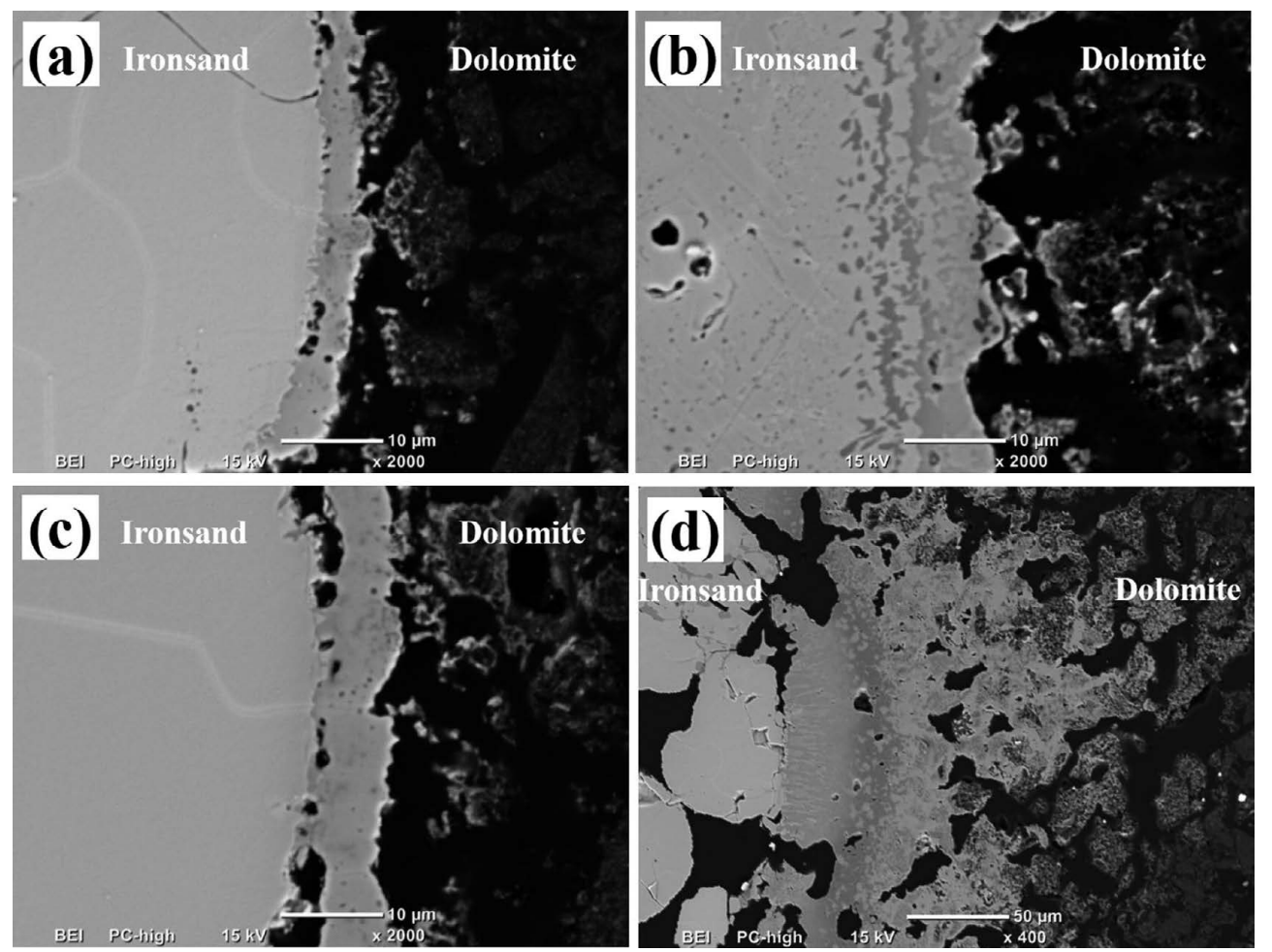

Fig. 10. BSE images of the interaction couples of ironsand and dolomite sintered under different conditions. (a) $1200^{\circ} \mathrm{C}, 4 \mathrm{~min}$; (b) $1200^{\circ} \mathrm{C}, 20 \mathrm{~min}$; (c) $1250^{\circ} \mathrm{C}, 4 \mathrm{~min}$; (d) $1300^{\circ} \mathrm{C}, 4 \mathrm{~min}$.

$$
\begin{aligned}
& \mathrm{CaMg}\left(\mathrm{CO}_{3}\right)_{2}(\mathrm{~s})=\mathrm{CaCO}_{3}(\mathrm{~s})+\mathrm{MgO}(\mathrm{s})+\mathrm{CO}_{2}(\mathrm{~g}) \\
& \mathrm{CaCO}_{3}(\mathrm{~s})=\mathrm{CaO}(\mathrm{s})+\mathrm{CO}_{2}(\mathrm{~g})
\end{aligned}
$$

As a result, the interaction between ironsand and dolomite layers practically involved ironsand with $\mathrm{CaO}$ and $\mathrm{MgO}$. This was investigated in an atmosphere of $\mathrm{pO}_{2}=$ $0.5 \mathrm{kPa}$ in the temperature range of $1200-1325^{\circ} \mathrm{C}$ for different times. The morphological changes of the interaction couples with sintering temperature and time were observed, as shown in Fig. 10. A reaction zone was formed between

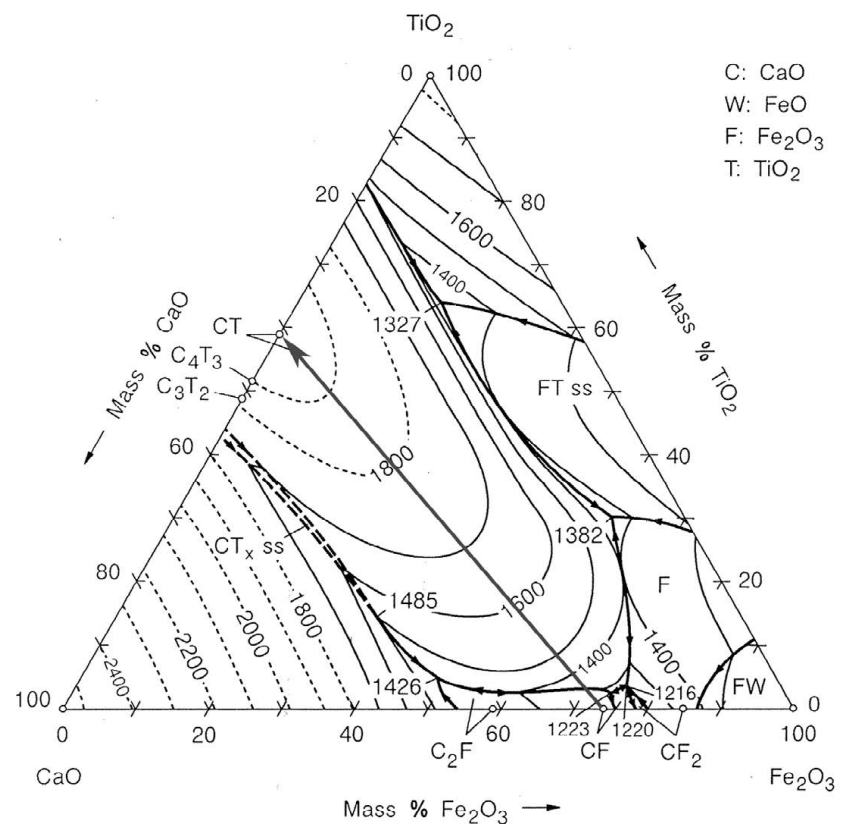

Fig. 9. Liquidus temperature of $\mathrm{CaO}-\mathrm{TiO}_{2}-\mathrm{FeO}_{\mathrm{x}}$ system. $^{10)}$ 
formation of the reaction zone was significantly enhanced with a distinct increase in the average thickness to over 100 $\mu \mathrm{m}$. The reaction zone consisted of several different subzones as shown by their difference in brightness.

Figure 11 shows the BSE images and EDS mapping of the interaction couple between ironsand and dolomite heated at $1300^{\circ} \mathrm{C}$ for $20 \mathrm{~min}$. Discrete titanomagnetite particles with very limited $\mathrm{Ca}$ and $\mathrm{Mg}$ concentrations were present within the ironsand layer (area 'a'). A coarsened (diffused edge on the dolomite side) reaction zone with broad penetration of $\mathrm{Fe}$ and $\mathrm{Ti}$ into the dolomite layers was observed. From the elemental distribution of the reaction zone, Fe, $\mathrm{Ca}$, $\mathrm{Ti}$ and $\mathrm{Mg}$ were non-uniformly distributed. At least three subzones can be identified, one being the broadest part which penetrated into the dolomite layer and contained high levels of $\mathrm{Fe}$ and $\mathrm{Ca}$, while another was close to the unreacted ironsand layer with relatively high $\mathrm{Ti}$ and $\mathrm{Ca}$ contents, which formed a discontinuous boundary on the ironsand layer. Between these two subzones was a band appearing similar to the perovskite band observed in the sintered ironsand and $\mathrm{CaO}$ reaction couple, but containing a significant amount of $\mathrm{Mg}$. The first broadest subzone was represented by the areas ' $c$ ' and ' $d$ ' in the BSE image in Fig. 11, and the last two narrow subzones were included in area ' $b$ '.

The BSE images of the four different typical areas in Fig. 11 are shown in Fig. 12 at higher magnification. The chemical compositions at different points marked in Fig. 12 were examined by EDS analysis and summarised in Table 4. As shown in Fig. 12(a), the morphology of the ironsand layer after sintering at $1300^{\circ} \mathrm{C}$ for 20 min was very similar to that occurring in sintered reaction couples of ironsand and $\mathrm{MgO}$ (Fig. 3). The ironsand particles remained intact and were weakly bonded by narrow necks. A small amount of silicate bonding phase (Points 3 and 4) contained relatively low concentrations of $\mathrm{Ca}$ and $\mathrm{Mg}$, indicating that the assimilation between the ironsand particles which were located several particles away from the interface was not affected by the presence of dolomite. The concentrations of $\mathrm{Mg}$ and $\mathrm{Ca}$ in the relict titanomagnetite particles (Points 1 and 2) were also hardly changed.

Figure 12(b) shows the microstructure of the Ti-rich subzone and Mg-rich subzone in samples sintered at $1300^{\circ} \mathrm{C}$ for $20 \mathrm{~min}$. The Ti-rich subzone marked by Point 7 and next to the titanomagnetite (Points 5 and 6) proved to be com-
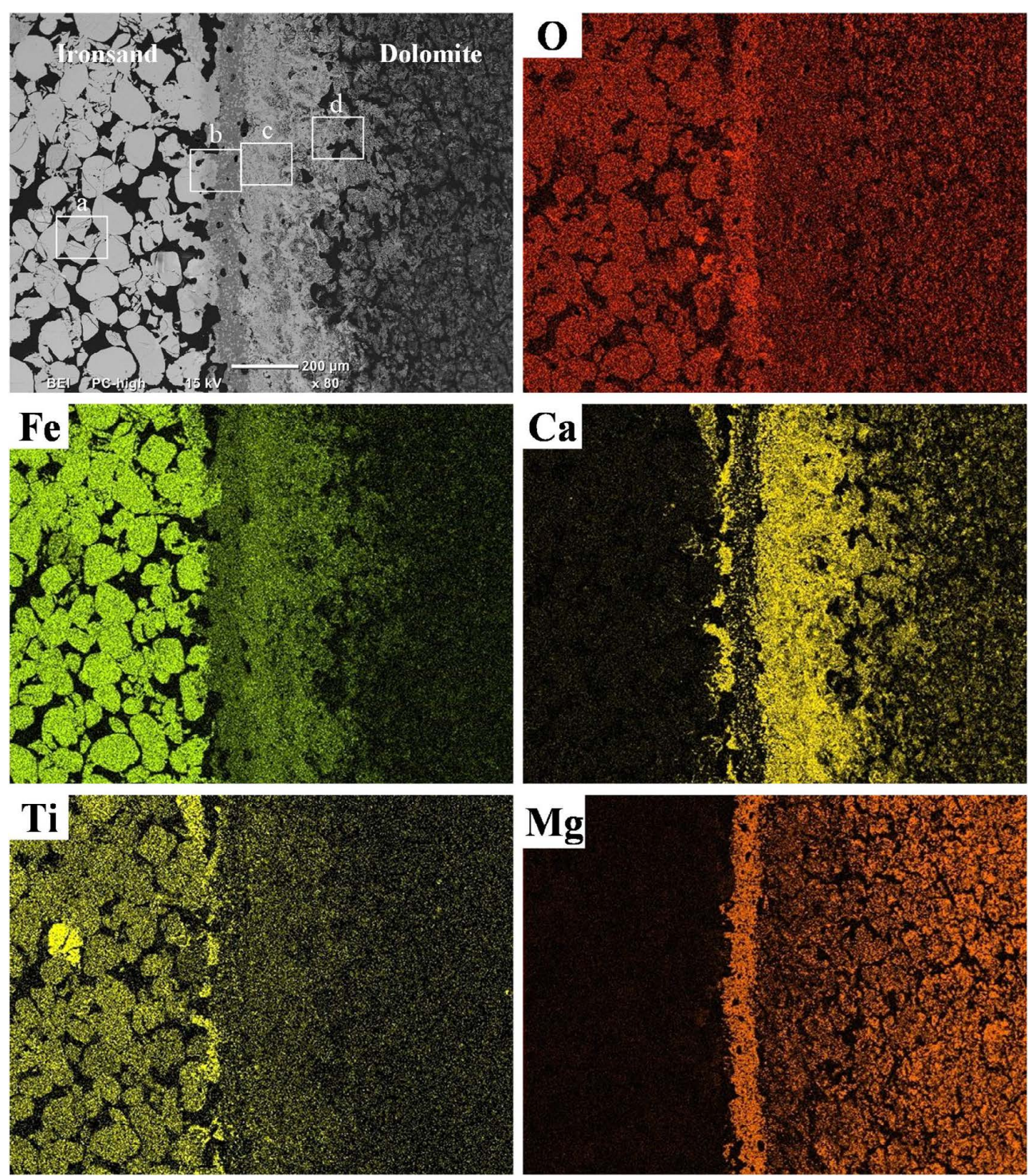

Fig. 11. BSE image and EDS mapping of an interaction couple between ironsand and dolomite sintered at $1300^{\circ} \mathrm{C}$ for $20 \mathrm{~min}$. The detailed information in areas $a$ through $d$ is presented in Fig. 12. (Online version in color.) 

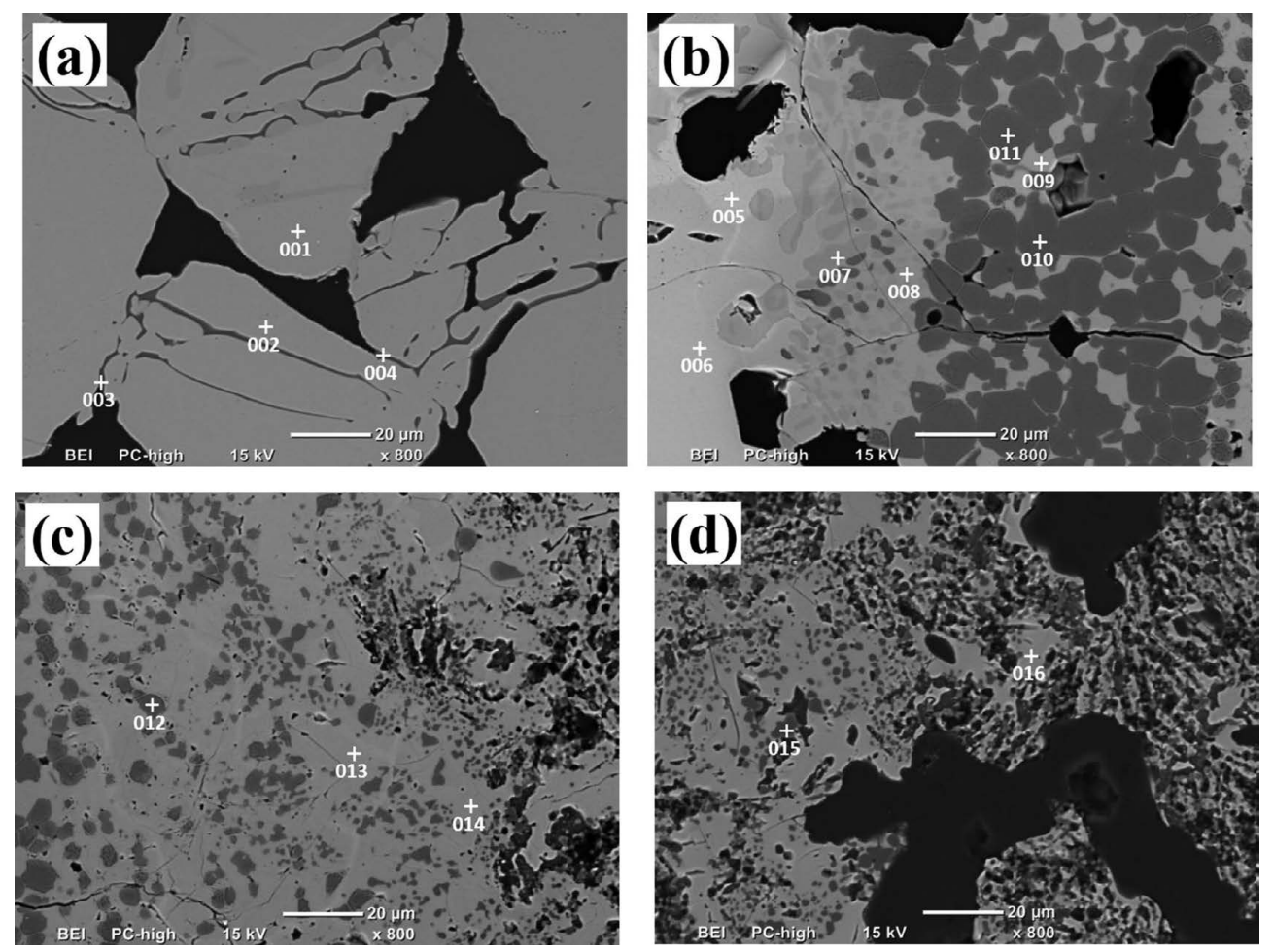

Fig. 12. BSE images of phases marked in Fig. 11.

Table 4. Elemental composition (wt\%) of grains marked in Fig. 12 and corresponding phases.

\begin{tabular}{ccrrrrrl}
\hline Point no. & \multicolumn{1}{c}{$\mathrm{Fe}$} & \multicolumn{1}{c}{$\mathrm{Ca}$} & \multicolumn{1}{c}{$\mathrm{Ti}$} & \multicolumn{1}{c}{$\mathrm{Mg}$} & \multicolumn{1}{c}{$\mathrm{Si}$} & $\mathrm{Al}$ & Phase identified \\
\hline 1 & 65.9 & 0.4 & 5.6 & 3.0 & 0.3 & 1.9 & Titanomagnetite \\
2 & 68.1 & 0.2 & 4.8 & 2.6 & 0.3 & 1.4 & Titanomagnetite \\
3 & 21.0 & 3.5 & 4.3 & 1.9 & 20.9 & 5.8 & Silicate \\
4 & 16.7 & 5.7 & 5.2 & 1.6 & 22.8 & 7.3 & Silicate \\
5 & 65.3 & 1.3 & 1.1 & 7.0 & 0.4 & 1.7 & Titanomagnetite \\
6 & 67.5 & 0.5 & 1.5 & 4.1 & 0.3 & 1.6 & Titanomagnetite \\
7 & 12.4 & 26.5 & 22.4 & 1.1 & 0.6 & 0.9 & Perovskite \\
8 & 20.4 & 27.4 & 15.4 & 1.7 & 1.5 & 1.2 & Perovskite \\
9 & 25.5 & 27.3 & 10.4 & 1.7 & 0.9 & 0.9 & Perovskite \\
10 & 25.9 & 0.3 & 0.5 & 42.0 & 0.4 & 0.8 & MgO-FeO \\
11 & 24.5 & 0.8 & 0.7 & 44.7 & 0.3 & 0.9 & MgO-FeO \\
12 & 24.4 & 0.6 & 0.4 & 43.4 & 0.4 & 1.1 & MgO-FeO \\
13 & 33.7 & 28.2 & 3.8 & 2.1 & 1.0 & 1.4 & Calcium ferrite \\
14 & 36.9 & 28.7 & 1.8 & 1.8 & 0.5 & 1.3 & Calcium ferrite \\
15 & 6.2 & 0.7 & 0.4 & 59.7 & 0.4 & 0.4 & MgO-FeO \\
16 & 36.7 & 28.4 & 2.3 & 2.3 & 0.6 & 1.2 & Calcium ferrite \\
\hline
\end{tabular}

plex perovskite phase containing some Fe. The phase with brightness between perovskite and titanomagnetite (Point 8), which was also found to be distributed in the dark grey area (Point 9), was another form of perovskite containing less Ti but more Fe. The Mg-rich band shown in Fig. 11 was seen to consist of round dark grey grains (Points 10 and 11), and contained mainly $\mathrm{MgO}-\mathrm{FeO}$ solid solution. The microstructure of the subzone rich in $\mathrm{Fe}$ and $\mathrm{Ca}$ is presented in Fig. 12(c), which was found, as expected, to mainly consist of

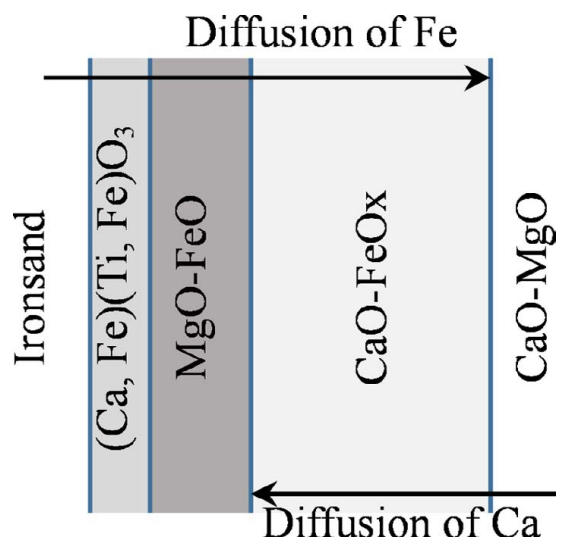

Fig. 13. A diffusion model describing phase formation during sintering of an interaction couple between ironsand and dolomite. (Online version in color.)

calcium ferrite (Points 13 and 14) but also contained discrete fine particles of $\mathrm{MgO}-\mathrm{FeO}$ solid solution (Point 12). Figure 12(d) shows the penetration of calcium ferrite particles into the dolomite layer. A large amount of fine calcium ferrite particles and $\mathrm{MgO}-\mathrm{FeO}$ particles (Point 15) were distributed in the dolomite layer.

The mechanisms of phase formation in the interaction couple of ironsand and dolomite can be summarised in Fig. 13. During sintering, $\mathrm{Mg}^{2+}$ and $\mathrm{Ca}^{2+}$ ions from the dolomite $(\mathrm{MgO}$ and $\mathrm{CaO}$ ) layer diffused towards the ironsand layer, while $\mathrm{Fe}^{2+}, \mathrm{Fe}^{3+}$ and $\mathrm{Ti}^{4+}$ ions from ironsand diffused in the opposite direction into $\mathrm{MgO}$ and $\mathrm{CaO}$. Consequently, the reaction zone which was rich in $\mathrm{Ca}, \mathrm{Fe}, \mathrm{Mg}$ and $\mathrm{Ti}$ was generated between the two layers. Since $\mathrm{Ti}^{4+}$ diffused at a slower rate than $\mathrm{Fe}^{2+}$ and $\mathrm{Fe}^{3+}$, a perovskite phase was formed as a result of reaction between $\mathrm{CaO}$ and accumulated $\mathrm{TiO}_{2}$ close to the relict ironsand layer. This perovskite acted as a barrier to the diffusion of $\mathrm{Mg}^{2+}$ ions, which accumu- 
lated next to the perovskite layer and combined with $\mathrm{Fe}$ to form a $\mathrm{FeO}-\mathrm{MgO}$ solid solution. In Fig. 12(a), the contents of $\mathrm{Mg}$ in silicate bonding phase and ironsand were low, since the prescence of perovskite phase hindered the diffusion of $\mathrm{Mg}$ into ironsand layer. In contrast, in sintered ironsand-MgO couple shown in Fig. 3, Mg significantly diffused into ironsand layer and benefited the generation of silicate bonding phase. This $\mathrm{FeO}-\mathrm{MgO}$ solid solution hindered further diffusion of $\mathrm{CaO}$ towards the ironsand layer. Finally, further phase formation was due to the relatively higher diffusion rates of $\mathrm{Fe}^{2+}$ and $\mathrm{Fe}^{3+}$ through the perovskite and $\mathrm{MgO}-\mathrm{FeO}$ solution barriers, and $\mathrm{Fe}$ and $\mathrm{Ca}$ combined to form calcium ferrite phase close to the $\mathrm{CaO}-\mathrm{MgO}$ layer. This mechanism explains why $\mathrm{Mg}$ and $\mathrm{Ca}$ can individually diffuse into the titanomagnetite matrix and even penetrate deeply into the ironsand layers, but very little diffuses into the ironsand layer from the $\mathrm{MgO}-\mathrm{CaO}$ mixture. It also shows that the assimilation process developed mainly in the direction of the $\mathrm{MgO}-\mathrm{CaO}$ layer through the diffusion of $\mathrm{Fe}$.

With increasing sintering temperature, the calcium ferrite phase (low melting point) in the Fe-rich subzone started to melt first and promoted futher spread of calcium ferrite into the dolomite layer, as shown in Fig. 11. The perovskite phase and $\mathrm{MgO}-\mathrm{FeO}$ solid solution remained stable at the higher sintering temperature due to their higher melting points.

\section{Conclusions}

In this study, the reaction couples between ironsand and flux materials $(\mathrm{CaO}, \mathrm{MgO}$ and dolomite) were sintered in an atmosphere of $\mathrm{pO}_{2}=0.5 \mathrm{kPa}$ in the temperature range of $1200-1300^{\circ} \mathrm{C}$ for different times. The main conclusions are as follows.

(1) $\mathrm{Mg}^{2+}$ ions significantly diffused into the lattice of ironsand when the ironsand was sintered with $\mathrm{MgO}$, which stabilised the system of $\mathrm{FeO}_{\mathrm{x}}-\mathrm{MgO}$ and hindered the assimilation of ironsand particles.

(2) During sintering of ironsand with $\mathrm{CaO}$, a reaction zone consisting of perovskite and calcium ferrite occurred between the two layers. When sintered at higher temperature $\left(1300^{\circ} \mathrm{C}\right)$, the ironsand particles were intimately bonded by mainly perovskite and a lesser amount of silicate phases. Partial melting of calcium ferrite phase greatly promoted mass transfer and futher penetration of calcium ferrite into the $\mathrm{CaO}$ layer.

(3) In terms of sintering of ironsand with dolomite, perovskite and calcium ferrite were also generated in the reaction zone. A $\mathrm{MgO}-\mathrm{FeO}$ solid solution was formed close to the perovskite phase, since the formation of perovskite phase hindered further diffusion of $\mathrm{Mg}^{2+}$ ions into the ironsand layer. Increasing sintering temperature significantly enhanced the penetration of calcium ferrite phase into the dolomite layer; whereas the perovskite phase and $\mathrm{MgO}-\mathrm{FeO}$ solid solution remained at high sintering temperature due to their higher melting points, which hindered penetration of $\mathrm{Ca}$ and $\mathrm{Mg}$ into the ironsand layer and suppressed the bonding between ironsand particles.

\section{Acknowledgements}

The project is financially supported by the BlueScope Steel Metallurgical Centre Projects Grant. The authors would like to acknowledge the Electron Microscopy Center (EMC) at University of Wollongong for SEM/EDS analysis.

\section{REFERENCES}

1) H. A. Cocker, J. L. Mauk, H. Rogers, A. B. Padya and J. Ogiliev: Proc. AusIMM New Zealand Branch 43rd Annual Conf., AusIMM New Zealand Branch, Alexandra, (2010), 165.

2) J. B. Wright: N. Z. J. Geol. Geophys., 7 (1964), 424.

3) J. B. Wright and J. F. Lovering: Mineral. Mag., 35 (1965), 604.

4) Z. Wang, D. Pinson, S. Chew, H. Rogers, B. J. Monaghan, M. I. Pownceby, N. A. S. Webster and G. Zhang: Metall. Mater. Trans. B, 47 (2016), 330.

5) M. B. Turner, S. J. Cronin, R. B. Stewart, M. Bebbington and I. E. M. Smith: Geology, 36 (2008), 31.

6) N. J. Bristow and C. E. Loo: ISIJ Int., 32 (1992), 819.

7) L. H. Hsieh and J. A. Whiteman: ISIJ Int., 29 (1989), 625

8) N. Rogers: An Introduction to Our Dynamic Planet, Cambridge University Press, Cambridge, (2008), 146.

9) C. V.A. Duke and C. D. Williams: Chemistry for Environmental and Earth Sciences, CRC Press, Boca Raton, (2007), 76.

10) K. C. Mills: Slag Atlas, 2nd ed., Verlag Stahleisen GmbH, Düsseldorf, (1995).

11) M. Binnewies and E. Milke: Thermochemical Data of Elements and Compounds, 2nd ed., Wiley-VCH Verlag GmbH, Weinheim, (2002). 